\title{
pH regulates the lumen diameter of tissue-engineered capillaries
}

\author{
XIAOLIN WANG, JING LI, YONGQIAN BIAN, CONGYING ZHAO, JINQING LI and XUEYONG LI \\ Department of Plastic and Burn Surgery, The Second Affiliated Hospital, Air Force Medical University, \\ Xi'an, Shaanxi 710038, P.R. China
}

Received September 29, 2021; Accepted December 3, 2021

DOI: $10.3892 /$ etm.2022.11212

\begin{abstract}
Angiogenesis is vital in tissue engineering and the size of the capillary lumen diameter directly affects vascular function. Therefore, the involvement of the $\mathrm{pH}$ in the regulation of the capillary lumen diameter was investigated in the present study. The cytosolic $\mathrm{pH}$ of different $\mathrm{pH}$ medium groups was measured using flow cytometry. Bromodeoxyuridine staining and wound-healing assays were performed to detect cell proliferation and migration, respectively. The expression of angiogenesis-related genes was detected using reverse transcription-quantitative PCR. In addition, cell tube formation under different $\mathrm{pH}$ conditions was assessed using a tube formation assay and a 3D Matrigel ${ }^{\circledR}$ model. The results indicated that a change in the $\mathrm{pH}$ value of the culture medium affected the cytosolic $\mathrm{pH}$ of the endothelial cells, which then led to a change in vascular diameter. When the medium's $\mathrm{pH}$ ranged from 7.4 to 7.6, the diameter of the lumen formed in the Matrigel was suitable for capillary formation in tissue engineering. The present results revealed an important role for the $\mathrm{pH}$ in the process of capillary formation and provided insight for $\mathrm{pH}$ regulation during endothelial cell tube formation and angiogenesis in tissue engineering.
\end{abstract}

\section{Introduction}

The lumen diameter directly affects the physiological function of capillaries and understanding its regulatory mechanism is important for the construction of functional tissue-engineered capillaries $(1,2)$. If the diameter of the capillary lumen is too small, the passage of blood cells will be affected, causing damage to blood and vascular endothelial cells (3). When the lumen diameter is too large, it may result in an ineffective exchange of nutrients and metabolites between tissues and blood, leading to tissue hypoxia and accumulation of

Correspondence to: Dr Jinqing Li or Dr Xueyong Li, Department of Plastic and Burn Surgery, The Second Affiliated Hospital, Air Force Medical University, 569 Xinsi Road, Xi'an, Shaanxi 710038, P.R. China

E-mail: lijqfmmu@163.com

E-mail: 1in_323@126.com

Key words: $\mathrm{pH}$, angiogenesis, capillary diameter, tissue engineering metabolites (4,5). However, the mechanisms underlying regulation of the capillary lumen diameter remain to be fully elucidated.

During wound healing, the $\mathrm{pH}$ of the surface layer of the granulation tissue is low ( $\mathrm{pH} 5.8-6.0)$; the $\mathrm{pH}$ of the granulation tissue in the proliferative stage is 6.4-7.0 and the $\mathrm{pH}$ of the deep layer is close to that of the plasma ( $\mathrm{pH} 7.3-7.6)(6,7)$. In tumor specimens, the capillaries near the center of the tumor tissue (pH 5.8-6.6) are relatively small in diameter or even without any definite lumen formation, while those near the edge of the tumor tissue (plasma pH 7.3-7.4) have larger lumen diameters $(7,8)$. This suggests that the $\mathrm{pH}$ of the peripheral environment is one of the key factors that regulate the lumen diameter of newly formed capillaries.

However, $\mathrm{pH}$, as a parameter for assessing the overall outcome, is not well studied, as the effect of the $\mathrm{pH}$ on the diameter of capillaries during neovascularization is rarely reported. Therefore, the present study aimed to explore the role of the $\mathrm{pH}$ in determining the vascular lumen diameter of new vessels.

\section{Materials and methods}

Cell culture. Human dermal microvascular endothelial cells (HDMECs; cat. no. 2000; ScienCell Research Laboratories, Inc.) were cultured according to the manufacturer's protocol in an endothelial cell medium (cat. no. 1001; ScienCell Research Laboratories, Inc.) supplemented with $5 \%$ fetal bovine serum (ScienCell Research Laboratories, Inc.), $100 \mathrm{U} / \mathrm{ml}$ penicillin-G, $100 \mathrm{U} / \mathrm{ml}$ streptomycin and $1 \%$ endothelial cell growth supplement (ScienCell Research Laboratories, Inc.). The cells were cultivated in $35-\mathrm{cm}^{2}$ culture flasks at $37^{\circ} \mathrm{C}$ under $5 \% \mathrm{CO}_{2}$ in air. The culture medium was replaced every $24 \mathrm{~h}$. The cells in passage 4 to 5 were used for experimentation. All experiments reported in this study were performed in triplicate.

Preparation of different $\mathrm{pH}$ media. Different concentrations of $\mathrm{NaOH}$ and hydroxyethyl piperazine ethanesulfonic acid were added into the endothelial cell medium and the $\mathrm{pH}$ of the medium was adjusted to $6.4,6.6,6.8,7.0,7.2,7.4,7.6$ and 7.8 using a pH meter (model PB-10; Sartorius AG). A $0.22-\mu \mathrm{m}$ membrane was used to filter the medium and remove bacteria, after which it was stored at $4^{\circ} \mathrm{C}$ until use.

Cytosolic pH determined using flow cytometry. Cytosolic $\mathrm{pH}$ was assessed through flow cytometry using the $\mathrm{pH}$-sensitive 
fluorescent probe 2,7-bis-(2-carboxyethyl)-5-(and-6)carboxyfluorescein, acetoxymethyl ester (BCECF-AM; cat. no. ab143463; Abcam). The cells incubated in media with different $\mathrm{pH}$ for $12 \mathrm{~h}$ and were harvested by centrifugation and incubated in a culture medium containing $4 \mu \mathrm{M}$ BCECF-AM in the dark at $37^{\circ} \mathrm{C}$ for $30 \mathrm{~min}$. The cells were washed with PBS and quantitative analysis of intracellular fluorescence was performed using a flow cytometer (BD FACSCalibur ${ }^{\mathrm{TM}}$; BD Biosciences). Data analysis was performed using the CELLQuest software tool (version 5.1; BD Biosciences).

Cell proliferation assay. The cells $\left(5 \times 10^{5}\right.$ cell $\left./ \mathrm{ml}\right)$ were grown on polylysine-coated glass coverslips and stained with an anti-bromodeoxyuridine (BrdU) antibody (1:500 dilution; cat. no. B35128; Thermo Fisher Scientific, Inc.) at $4^{\circ} \mathrm{C}$ overnight. The coverslips were washed with PBS and the cells were fixed with $4 \%$ paraformaldehyde for $15 \mathrm{~min}$ at $23^{\circ} \mathrm{C}$. The coverslips were placed in $2 \mathrm{~mol} / 1 \mathrm{HCl}$ for $30 \mathrm{~min}$ and washed with PBS. The cells were incubated with goat anti-mouse $\mathrm{Cy} 3$-conjugated secondary antibodies $(1: 1,000$; cat. no. ab97035; Abcam) at $37^{\circ} \mathrm{C}$ for $2 \mathrm{~h}$ and then blocked with PBS containing 5\% goat serum (cat. no. ab7481; Abcam) at room temperature for $1 \mathrm{~h}$. Finally, the cells were stained with 4',6-diamidino-2-phenylindole for $10 \mathrm{~min}$ at room temperature and examined using a fluorescence microscope (Olympus IX 71 fluorescence microscope; Olympus Corporation).

Wound-healing assay. A wound-healing assay was used to evaluate the migratory behavior of HDMECs in media at varying $\mathrm{pH}$. In brief, the cells were labeled with CellTracker ${ }^{\mathrm{TM}}$ (cat. no. C2925; Invitrogen; Thermo Fisher Scientific, Inc.) according to the manufacturer's protocol, and then confluent cells were scratched with a $200-\mu 1$ micropipette tip to create a consistent wound gap in the middle. The cells were washed with PBS to remove any cell debris and media of varying $\mathrm{pH}$ without serum were added to allow wound healing. Images of the wound gap were acquired using a fluorescence microscope (Olympus IX 71; Olympus Corporation) at 0,24 and $48 \mathrm{~h}$ at three random locations in each well to examine the distance of wound closure. Image-Pro Plus software (version 6.0; Media Cybernetics, Inc.) was used to calculate the migration rate.

Reverse transcription-quantitative PCR (RT-qPCR). RT-qPCR was performed to detect the expression of endothelial angiogenesis-related genes [VEGFA, angiopoietin 1 (ANG1) and CD31] at different pH. Total RNA was extracted from the different groups of cells using a Takara MiniBEST Universal RNA Extraction kit (cat. no. 9767; Takara Bio, Inc.), according to the manufacturer's protocol. RT reactions were performed with PrimeScript ${ }^{\mathrm{TM}}$ RT Master Mix (cat. no. RR036A; Takara Bio, Inc.) according to the manufacturer's protocol. qPCR was performed using TB Green ${ }^{\mathrm{TM}}$ Premix Ex Taq II (cat. no. RR820A; Takara Bio, Inc.) according to the manufacturer's protocol. The PCR amplifications were performed in Real Time Instrument (CFX Connect Real Time PCR system, Bio-Rad Laboratories, Inc.). Thermocycling conditions were: Initial denaturation at $95^{\circ} \mathrm{C}$ for $2 \mathrm{~min} ; 40$ cycles of denaturation at $95^{\circ} \mathrm{C}$ for $15 \mathrm{sec}$, annealing and elongation at $60^{\circ} \mathrm{C}$ for $1 \mathrm{~min}$; then a final extension at $72^{\circ} \mathrm{C}$ for $3 \mathrm{~min}$. The mRNA expression levels of the target genes were quantified using the $2^{-\Delta \Delta C q}(9)$ method and normalized to those of GAPDH. The primers used for qPCR are listed in Table SI.

Tube formation on Matrigel ${ }^{\circledR}$. Endothelial cells rapidly attach, align and form capillary-like tubules on a reconstituted basement membrane matrix $(10,11)$. Cold liquid Matrigel (cat. no. 354234; BD Biosciences) was added to 96-well plates at a volume of $50 \mu \mathrm{l} /$ well and incubated at $37^{\circ} \mathrm{C}$ in an incubator containing humidified air with $5 \% \mathrm{CO}_{2}$ for $1 \mathrm{~h}$. After the Matrigel had solidified, fluorescently-labeled (CellTracker ${ }^{\mathrm{TM}}$; cat. no. C2925; Invitrogen; Thermo Fisher Scientific, Inc.) HDMECs $\left(2 \times 10^{4}\right.$ cells $\left./ 100 \mu \mathrm{l}\right)$ were seeded into each well and incubated in the conditioned medium at $37^{\circ} \mathrm{C}$. Images were acquired after $24 \mathrm{~h}$ with a fluorescence microscope (Olympus IX 71; Olympus Corporation) to evaluate the degree of tube formation, which was quantified by measuring the branch length in three randomly selected fields using Image J software (version 1.51; National Institutes of Health).

Tube formation in a 3D Matrigel model. The cell suspensions with different $\mathrm{pH}$ values were mixed with Matrigel and cultured in 48 -well plates under $5 \% \mathrm{CO}_{2}$ at $37^{\circ} \mathrm{C}$. The cell tubes were stained using toluidine blue at room temperature for $10 \mathrm{~min}$ after $48 \mathrm{~h}$ cultured, as described previously (12). To observe tube formation, the cells were photographed under a microscope (Olympus IX 71; Olympus Corporation) after 3 days. The degree of tube formation was quantified by measuring the lumen diameter using ImageJ software (version 1.51; National Institutes of Health).

Statistical analysis. Values are expressed as the mean \pm standard error of the mean of at least three independent experiments and all experiments were performed at least three independent repeats. Differences among groups were analyzed using one-way analysis of variance followed by Bonferroni correction for multiple comparisons. Statistical analysis was performed using SPSS 23.0 software (IBM Corporation). Figures were plotted using Origin 8.5 software (OriginLab Corporation).

\section{Results}

$\mathrm{pH}$ of the medium is tightly associated with the cytosolic $\mathrm{pH}$. First, the effect of media with different $\mathrm{pH}$ on the cytosolic $\mathrm{pH}$ was determined (Fig. 1). An association between the relative fluorescence and the $\mathrm{pH}$ of the medium was observed; the cytosolic $\mathrm{pH}$ increased steadily with the increase in the $\mathrm{pH}$ of the medium. The specific data for each group are presented in Fig. S1.

pH affects the proliferation and migration of HDMECs. To investigate whether $\mathrm{pH}$ affects the biological properties of vascular endothelial cells, the effects of media of varying $\mathrm{pH}$ on cell proliferation and migration were examined. The cell proliferation rate increased as the $\mathrm{pH}$ increased to 6.4-7.6, particularly at $\mathrm{pH}$ 7.2-7.6; however, the cell proliferation rate decreased at $\mathrm{pH} 7.8$ (Fig. 2A and B). The result of cell 


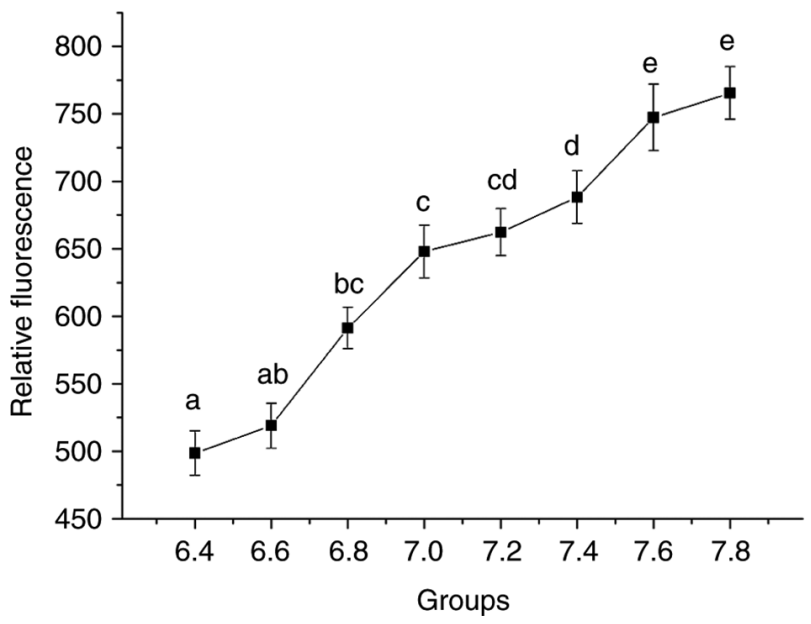

Figure 1. Relative fluorescence of each group in endothelial cells and different cytosolic $\mathrm{pH}$ levels analyzed using flow cytometry. The $\mathrm{X}$-axis represents the different $\mathrm{pH}$ groups and the $\mathrm{Y}$-axis the relative fluorescence. One-way analysis of variance and Bonferroni correction among groups was performed ${ }^{\mathrm{a}} \mathrm{P}<0.05$ vs. $6.8,7.0,7.2,7.4,7.6$ and $7.8 ;{ }^{\mathrm{b}} \mathrm{P}<0.05$ vs. 7.0, 7.2, 7.4, 7.6 and 7.8; ${ }^{\mathrm{c}} \mathrm{P}<0.05$ vs. $7.4,7.6$ and $7.8 ;{ }^{\mathrm{d}} \mathrm{P}<0.05$ vs. 7.6 and $7.8 ;{ }^{\mathrm{e}} \mathrm{P}<0.05$ vs. $6.4,6.6,6.8$, $7.0,7.2$ and 7.4

migration is analogous to proliferation. The cell images after 24 and $48 \mathrm{~h}$ revealed that HDMEC migration was significantly influenced by the $\mathrm{pH}$ (Fig. 3A and B). At $\mathrm{pH}$ values between 6.4 and 6.8 , the migratory rate of HDMECs into the wound gap after $24 \mathrm{~h}$ of culture was relatively low $(22 \%)$ and only moderate wound coverage $(\sim 50 \%)$ was achieved after 48 h. By contrast, HDMEC migration into the wound gap was markedly enhanced by increasing the $\mathrm{pH}$ from 7.0 to 7.6 ; the 'wound gap' was completely covered at pH 7.6 after 48 h. However, compared with $\mathrm{pH} 7.6$, the migratory rate of HDMECs decreased significantly at $\mathrm{pH} 7.8(\mathrm{P}<0.05)$.

pH influences the expression of angiogenesis-related genes. RT-qPCR analysis of the expression of angiogenesis-related genes further confirmed that the $\mathrm{pH}$ influenced their expression (Fig. 4). The expression of ANG1 gradually increased with the increase in $\mathrm{pH}$ and reached a maximum at $\mathrm{pH} 7.6$ (Fig. 4B). Similarly, the expression of VEGFA was significantly higher at $\mathrm{pH}$ 7.0-7.8 compared with at $\mathrm{pH}$ 6.4-6.8; however, it decreased from pH 7.6 to 7.8 (Fig. 4A). By contrast, the expression of CD31 was only slightly altered with the increase in the medium $\mathrm{pH}$ and the differences between the groups were not significant (Fig. 4C).

Medium pH affects tube formation. An HDMEC tube formation assay was performed to evaluate the effect of the media at different $\mathrm{pH}$ on tube formation. The cells were seeded on Matrigel and the formation of tube-like cell arrangements was assessed. The tube formation capacity of the cells was evaluated by determining the branch points and branch length of the tubes $(13,14)$. It was revealed that tube formation was significantly reduced at $\mathrm{pH}$ 6.4-7.0 compared with higher $\mathrm{pH}$ values (Fig. 5A). The histogram indicated that in comparison with those at $\mathrm{pH}$ 6.4-7.0, the number of branch points and the capillary length at $\mathrm{pH} 7.2,7.4,7.6$ and 7.8 were significantly increased, the highest being at $\mathrm{pH} 7.4$ and 7.6
$(\mathrm{P}<0.05$; Fig. 5B and $\mathrm{C})$. Therefore, the results indicated that 7.4 and 7.6 are the optimal $\mathrm{pH}$ values for HDMEC tube formation.

pH regulates lumen diameter in Matrigel. HDMECs formed tube-like structures in a 3D Matrigel model in media with different pH (Fig. 6). HDMECs formed tubules (Fig. 6A) and the diameter of the vascular tubules increased with an increase in the $\mathrm{pH}$ of the medium; however, at $\mathrm{pH} 7.8$, the diameter of the vascular tubules was decreased. The histogram in Fig. 6B indicated that the lumen diameter increased steadily from $\mathrm{pH}$ 6.4-7.6, and significantly decreased at $\mathrm{pH} 7.8(\mathrm{P}<0.05)$. These results indicated that the $\mathrm{pH}$ of the medium has an important role in lumen formation.

\section{Discussion}

The regulation of capillary lumen diameter is important in the formation of tissue-engineered capillaries (15-17). The lumen diameter directly influences the physiological function of capillaries and its regulation is of great significance for the construction of tissue-engineered organs (18). Capillaries in normal tissues have diameters of 5-10 $\mu \mathrm{m}(19,20)$. If the capillary lumen diameter is too small, it will affect the passage of blood cells, resulting in blood cell and vascular endothelial cell damage (21). On the other hand, if the capillary lumen diameter is too large, the velocity of blood flow decreases, affecting the rate of delivery of oxygen, nutrients, growth factors and circulating cells necessary for the body $(22,23)$.

In the present study, it was observed that the $\mathrm{pH}$ of the peripheral environment is a key factor in regulating the lumen diameter of newly formed capillaries. The extracellular $\mathrm{pH}$ affects the $\mathrm{pH}$ of the cytoplasm $(24,25)$. Furthermore, the relationship between the $\mathrm{pH}$ of the medium and that of the cell cytoplasm was studied. In HDMEC cultures, an increase in the $\mathrm{pH}$ of the culture medium led to an increase in the $\mathrm{pH}$ of the cytoplasm. However, these corresponding changes were not always consistent. This may be attributed to the buffering capacity of HDMECs. Therefore, a change in the $\mathrm{pH}$ of the culture medium was able to affect the cytoplasmic $\mathrm{pH}$ of HDMECs, leading to a change in vascular diameter.

In in vivo vascular systems, capillaries that are between 5 and $10 \mu \mathrm{m}$ in diameter are the only regions where nutrients and metabolites are able to be exchanged with tissues (19). The lumen diameter of capillaries from HDMECs formed in Matrigel was $\sim 10 \mu \mathrm{m}$ when the $\mathrm{pH}$ of the medium was 6.4-6.8. This size is suitable for forming capillaries in tissue engineering. This possibly suggests that smaller capillaries may be constructed using a medium with lower $\mathrm{pH}$. A higher cytosolic $\mathrm{pH}$ is associated with increased cell growth and proliferation in mammalian cells (26), which is consistent with the results of the present study. Cell proliferation tests indicated that the proliferation ratio increased with an increase in the medium $\mathrm{pH}$ from 6.4 to 7.6 , particularly at $\mathrm{pH} 7.2-7.6$, but it gradually decreased at $\mathrm{pH}$ 7.8. The expression of ANG1 and VEGFA exhibited a similar trend. These results reflect the difficulty in constructing capillaries with small diameters; however, they further confirmed that a medium $\mathrm{pH}$ of 7.2-7.6 is optimal for in vitro neovascularization with HDMECs. The expression of CD31 remained unaffected. Therefore, the $\mathrm{pH}$ possibly does 

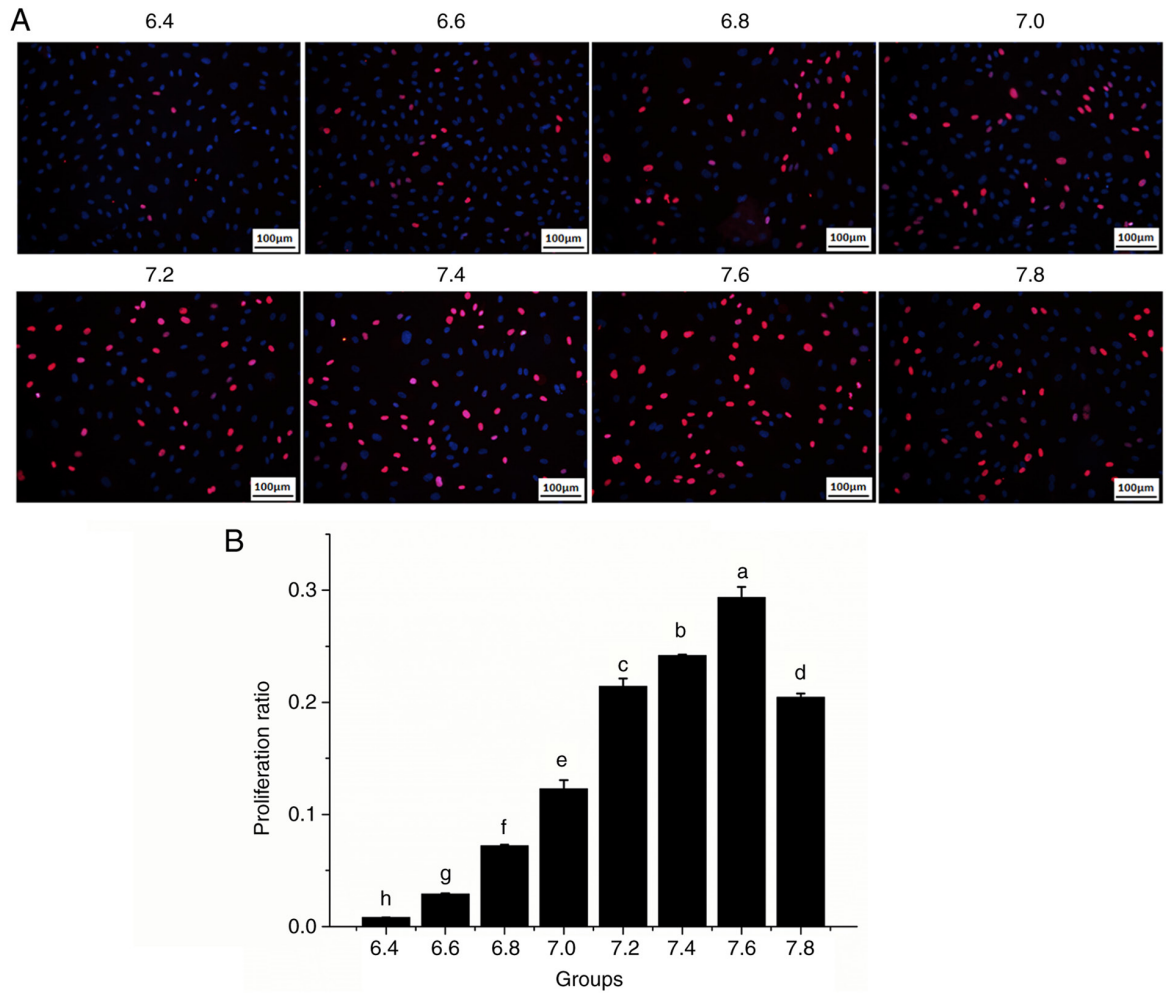

Figure 2. Proliferation of human dermal microvascular endothelial cells under different $\mathrm{pH}$ conditions. (A) Cells were subjected to bromodeoxyuridine immunofluorescence staining. Proliferating and normal cell nuclei were stained in red and blue, respectively (scale bars, $100 \mu \mathrm{m}$ ). (B) Quantification of the proliferation rate in each group. The $\mathrm{X}$-axis represents the different $\mathrm{pH}$ groups. One-way analysis of variance and Bonferroni correction among groups was performed. ${ }^{\mathrm{a}} \mathrm{P}<0.05$ vs. $7.4 ;{ }^{\mathrm{b}} \mathrm{P}<0.05$ vs. $7.2 ;{ }^{\mathrm{c}} \mathrm{P}<0.05$ vs. $7.8 ;{ }^{\mathrm{d}} \mathrm{P}<0.05$ vs. $7.0 ;{ }^{\mathrm{e}} \mathrm{P}<0.05$ vs. 6.8 ; ${ }^{\mathrm{f}} \mathrm{P}<0.05$ vs. $6.6 ;{ }^{\mathrm{g}} \mathrm{P}<0.05$ vs. 6.4 ; ${ }^{\mathrm{h}} \mathrm{P}<0.05$ vs. $6.6,6.8,7.0,7.2,7.4,7.6$ and 7.8
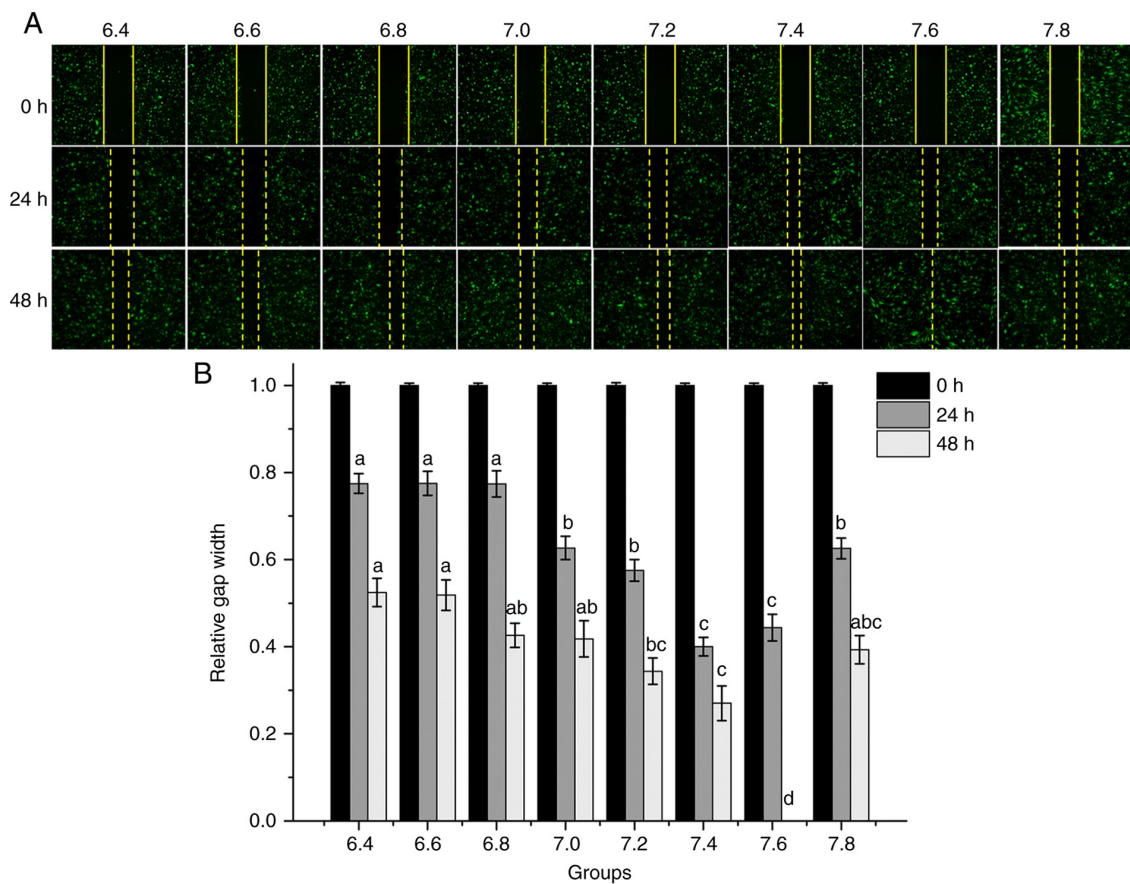

Figure 3. Migration of human dermal microvascular endothelial cells at different $\mathrm{pH}$ levels determined using a wound-healing assay. (A) Representative migration images (magnification, $\mathrm{x} 40$ ). Cells were allowed to migrate after the wound gaps were created and visualized after 24 and $48 \mathrm{~h}$. (B) Quantification of the wound gap distance between the front lines of migrating cells. The $\mathrm{X}$-axis represents the different $\mathrm{pH}$ groups. One-way analysis of variance and Bonferroni correction among groups was performed. $24 \mathrm{~h}$ : ${ }^{\mathrm{a}} \mathrm{P}<0.05$ vs. 7.0, 7.2, 7.4,7.6 and 7.8; ${ }^{\mathrm{b}} \mathrm{P}<0.05$ vs. 7.4 and $7.6 ; 48 \mathrm{~h}$ : ${ }^{\mathrm{a}} \mathrm{P}<0.05$ vs. $7.2,7.4$ and 7.6; ${ }^{\mathrm{b}} \mathrm{P}<0.05$ vs. 7.4 and $7.6 ;{ }^{\mathrm{C}} \mathrm{P}<0.05$ vs. $7.6 ;{ }^{\mathrm{d}} \mathrm{P}<0.05$ vs. $6.4,6.6,6.8,7.0,7.2,7.4$ and 7.8 .

not affect cell adhesion. Both the capillary length and branch points of the tubes were associated with an increased cytosolic
$\mathrm{pH}$. This is particularly important for the construction of capillaries in tissue-engineered organs. Furthermore, in a 

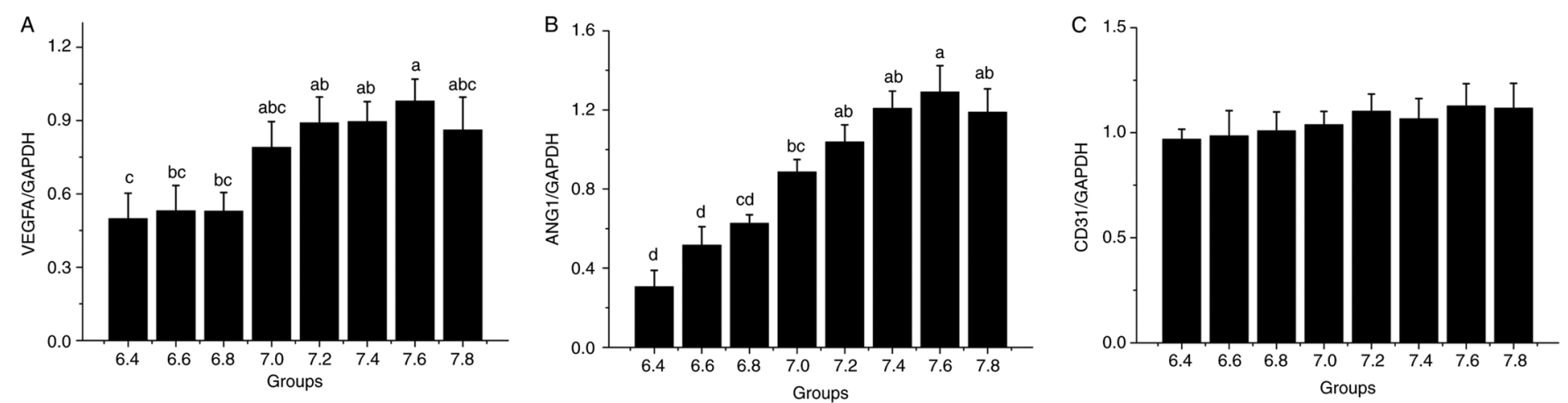

Figure 4. Reverse transcription-quantitative PCR analysis of genes related to angiogenesis. The X-axis represents the different $\mathrm{pH}$ groups. Relative levels of (A) VEGFA ( ${ }^{\mathrm{a}} \mathrm{P}<0.05$ vs. $6.4,6.6$ and $6.8 ;{ }^{\mathrm{b}} \mathrm{P}<0.05$ vs. 6.4 ; ${ }^{\mathrm{C}} \mathrm{P}<0.05$ vs. $7.2,7.4$ and 7.6), (B) ANG1 ( ${ }^{\mathrm{a}} \mathrm{P}<0.05$ vs. $6.4,6.6,6.8$ and 7.0 ; ${ }^{\mathrm{b}} \mathrm{P}<0.05$ vs. $6.4,6.6$ and 6.8 ; ${ }^{\mathrm{c}} \mathrm{P}<0.05$ vs. 6.4 and $6.6 ;{ }^{\mathrm{d}} \mathrm{P}<0.05$ vs. 7.0, 7.2, 7.4, 7.6 and 7.8) and (C) $\mathrm{CD} 31$. ANG1, angiopoietin 1.

A

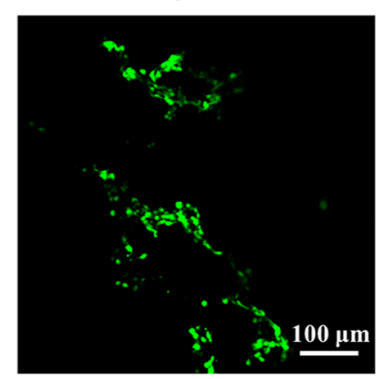

7.2

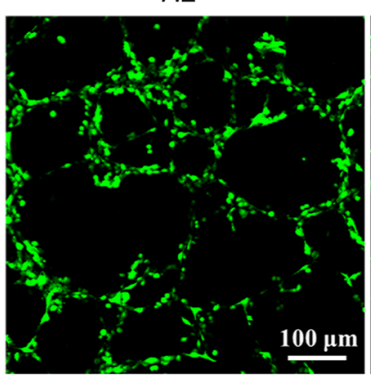

B
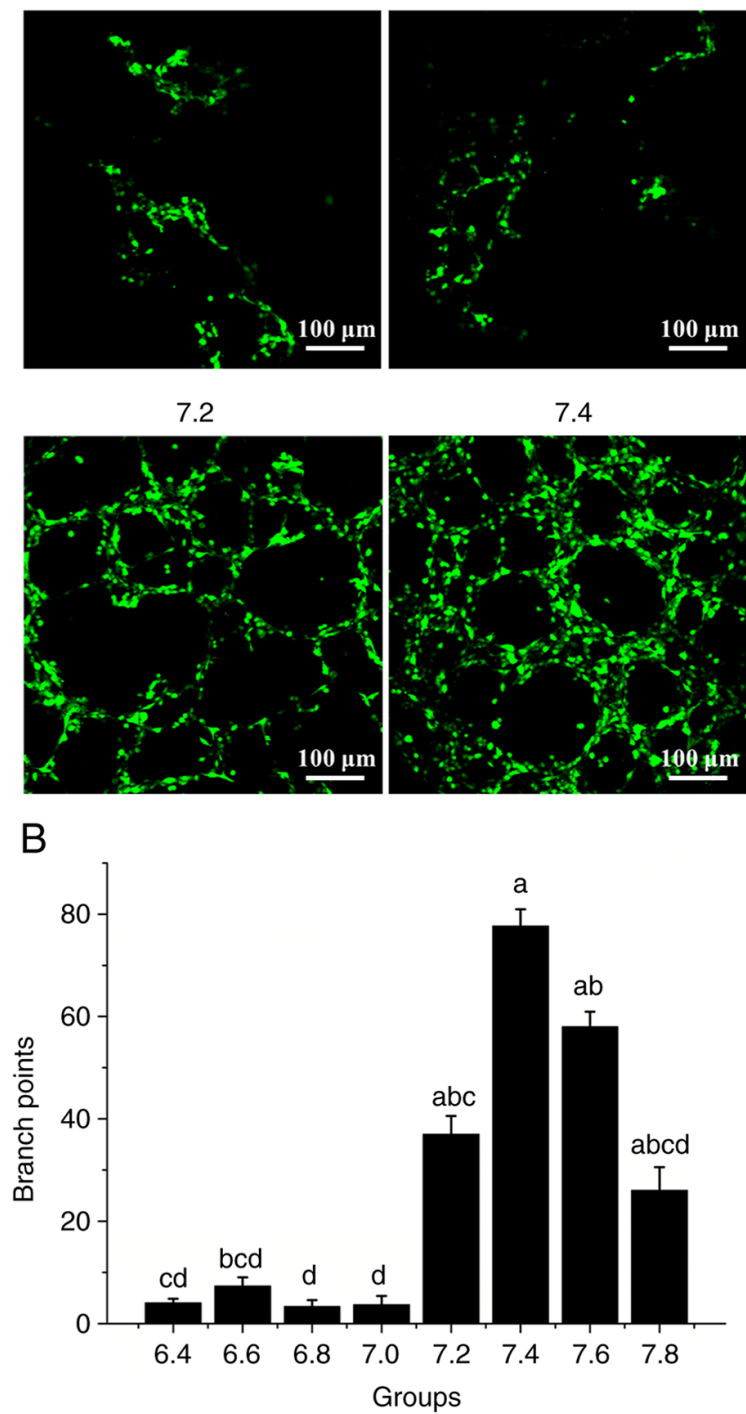

7.4

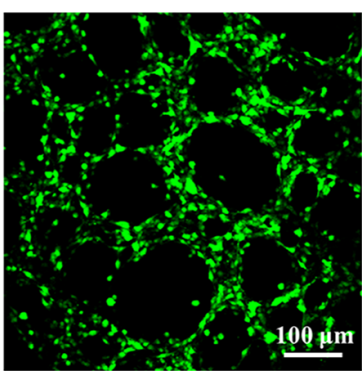

6.8

C

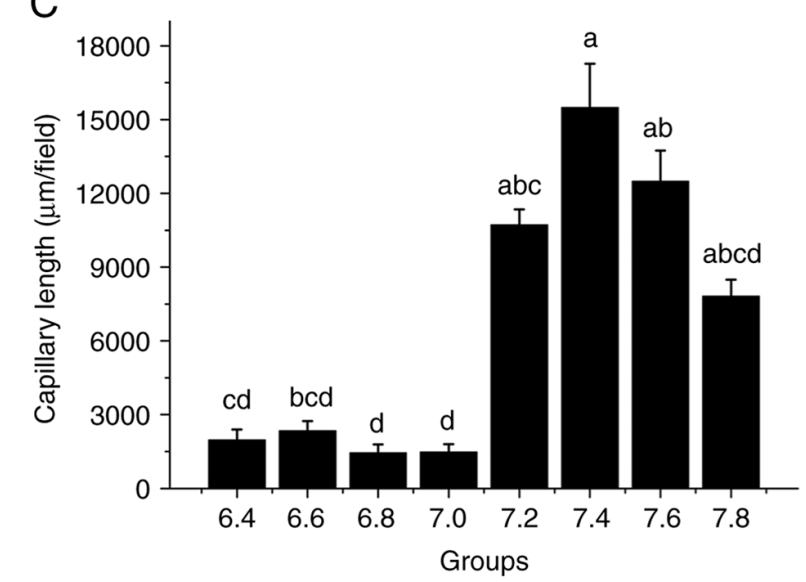

Figure 5. Tube formation of human dermal microvascular endothelial cells cultured on Matrigel. (A) Capillary tube formation on Matrigel (scale bars, $100 \mu \mathrm{m})$. Quantitative analysis of (B) branch points ( ${ }^{\mathrm{a}} \mathrm{P}<0.05$ vs. 6.4, 6.6, 6.8 and $7.0 ;{ }^{b} \mathrm{P}<0.05$ vs. 6.4, 6.8 and 7.0; ${ }^{\mathrm{c}} \mathrm{P}<0.05$ vs. 6.8 and $7.0 ;{ }^{\mathrm{d}} \mathrm{P}<0.05 \mathrm{vs} .7 .2,7.4$ and 7.6) and (C) total capillary length of the tubes formed on the Matrigel of different pH groups ( ${ }^{\mathrm{a}} \mathrm{P}<0.05$ vs. 6.4, 6.6, 6.8 and 7.0; ${ }^{\mathrm{b}} \mathrm{P}<0.05 \mathrm{vs}$. 6.4, 6.8 and 7.0; ${ }^{\mathrm{c}} \mathrm{P}<0.05$ vs. 6.8 and $7.0 ;{ }^{\mathrm{d}} \mathrm{P}<0.05$ vs. 7.2, 7.4 and 7.6). The $\mathrm{X}$-axis represents the different $\mathrm{pH}$ groups. One-way analysis of variance and Bonferroni correction among groups was performed.

previous study by Ye (27), wherein the acceptance rate of skin grafts in patients with acute and chronic wounds of different origin was observed, $99 \%$ of the skin grafts were successfully taken in wounds at a pH of 7.4 and higher; however, no 
A

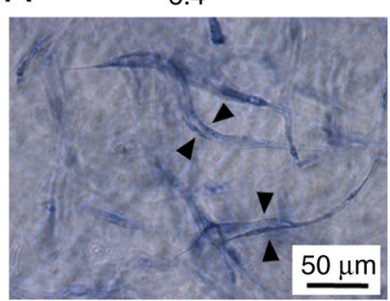

7.2

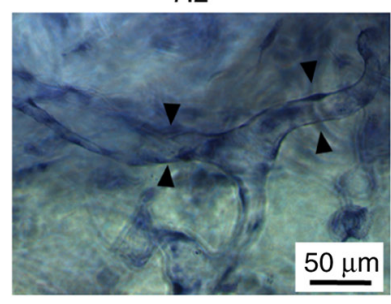

6.6

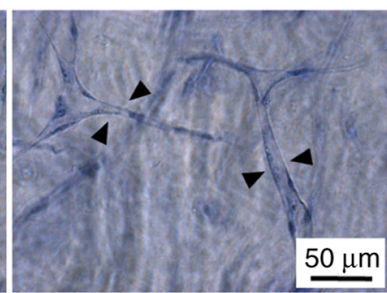

7.4

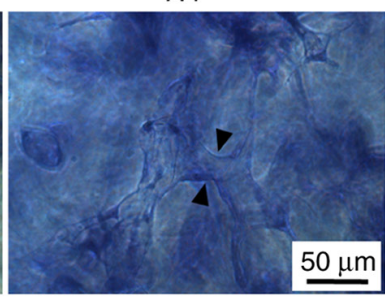

6.8

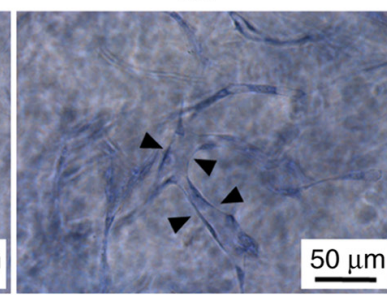

7.6

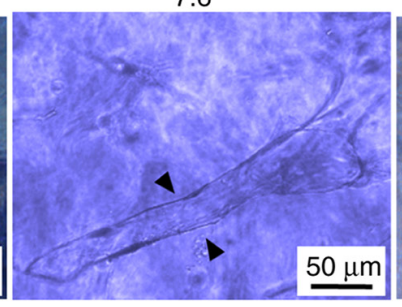

7.0

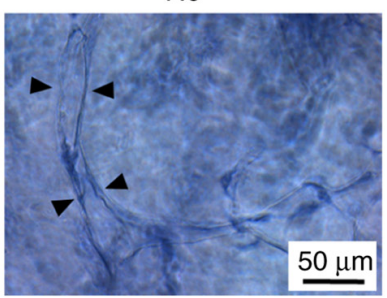

7.8

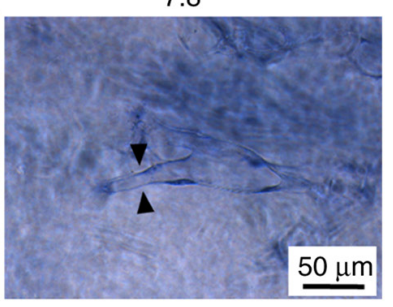

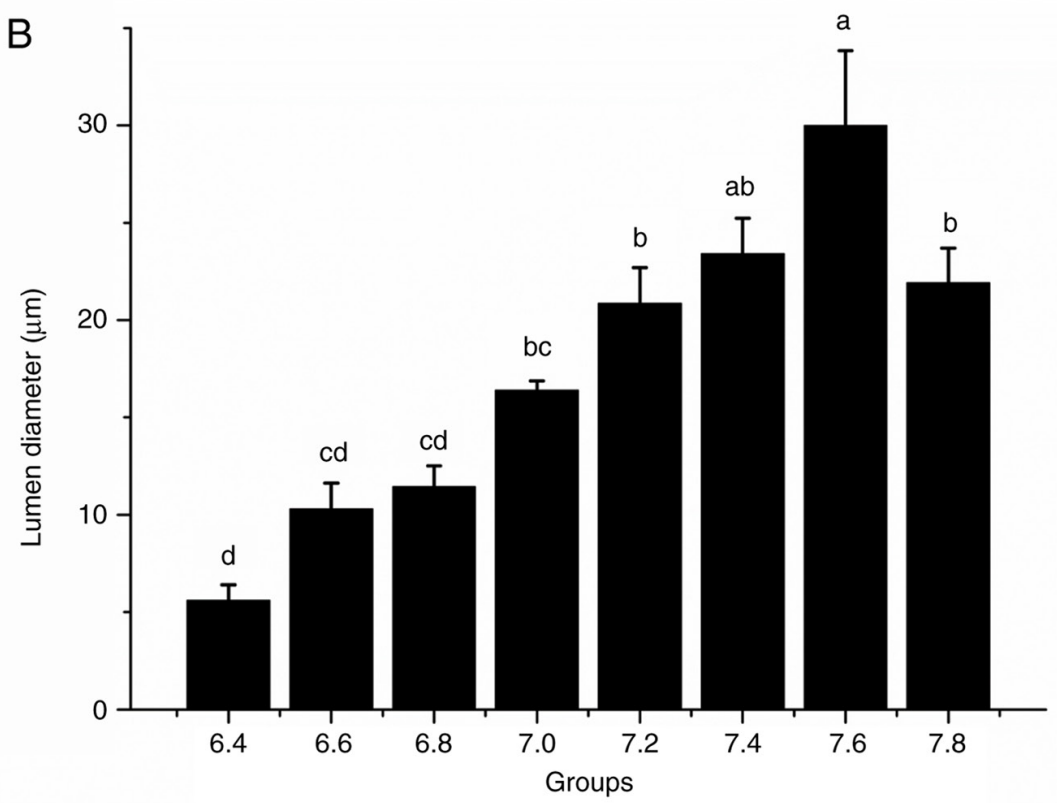

Figure 6. Three-dimensional HDMEC tubes in Matrigel. (A) Representative images of HDMEC tubes in Matrigel. The background of images may be different after toluidine blue staining due to staining in Matrigel, and the images with clear lumen were selected as the representative images. Black arrowheads indicate the cell tubes (scale bars, $50 \mu \mathrm{m}$ ). (B) Quantitative analysis of the lumen diameter of the endothelial cell tubes in each group. The X-axis represents the different $\mathrm{pH}$ groups. One-way analysis of variance and Bonferroni correction among groups was performed. ${ }^{\mathrm{a}} \mathrm{P}<0.05$ vs. $6.4,6.6,6.8,7.0,7.2$ and $7.8 ;{ }^{\mathrm{b}} \mathrm{P}<0.05$ vs. 6.4, 6.6 and $6.8 ;{ }^{\circ} \mathrm{P}<0.05$ vs. $6.4,7.2,7.4,7.6$, and $7.8 ;{ }^{\mathrm{d}} \mathrm{P}<0.05$ vs. 7.0, 7.2, 7.4, 7.6 and 7.8. HDMEC, human dermal microvascular endothelial cell.

skin graft was successfully taken in wounds at a $\mathrm{pH}<7.0$. In combination with the results of the present study, this may be due to the presence of appropriate growth conditions for capillaries at $\mathrm{pH} 7.4$ and 7.6, which provide sufficient blood supply, leading to improved wound healing.

Considering the results of cell proliferation, migration and tube formation, it was determined that the most optimal $\mathrm{pH}$ of the medium was 7.2-7.6 for in vitro neovascularization with HDMECs. This may be attributed to the closeness to the physiological $\mathrm{pH}$ of blood and extracellular fluids, which is in the range of 7.35-7.45 (28-30). At this appropriate $\mathrm{pH}$ range, the various enzymes had maximum activity, enabling improved formation of new blood vessels.

In conclusion, the present study observed that the $\mathrm{pH}$ regulated the diameter of the capillary lumen in HDMECs; the optimal $\mathrm{pH}$ was 7.4-7.6. However, the mechanisms underlying the regulation of the lumen diameter of capillaries by the $\mathrm{pH}$ remain to be fully elucidated. This will be our next research direction.

\section{Acknowledgements}

The authors would like to thank Professor Xiwang $\mathrm{Hu}$ (Experimental Center of the Third Affiliated Hospital of the Air Force Medical University) for his assistance with laser confocal microscopy.

\section{Funding}

This work was supported by grants from the National Natural Science Foundation of China (grant nos. 31570986 and 81701909). 


\section{Availability of data and materials}

The datasets used and/or analyzed during the current study are available from the corresponding author on reasonable request.

\section{Authors' contributions}

XW, JinqL and XL designed the study. XW and JingL wrote the manuscript. XW, YB and CZ performed the experiments and JingL analyzed the data. All authors read and approved the final manuscript and confirm the authenticity of the raw data.

\section{Ethics approval and consent to participate}

Not applicable.

\section{Patient consent for publication}

Not applicable.

\section{Competing interests}

The authors declare that they have no competing interests.

\section{References}

1. Wang Z, Mithieux SM and Weiss AS: Fabrication techniques for vascular and vascularized tissue Engineering. Adv Healthc Mater 8: e1900742, 2019.

2. Hati S, Agrawal S and Rai V: Vascular regeneration and tissue engineering: Progress, clinical impact, and future challenges Regenerated Organs 153-166, 2021.

3. Munisso MC and Yamaoka T: Circulating endothelial progenitor cells in small-diameter artificial blood vessel. J Artif Organs 23 6-13, 2020.

4. Hamilton NB, Attwell D and Hall CN: Pericyte-mediated regulation of capillary diameter: A component of neurovascular coupling in health and disease. Front Neuroenergetics 2: 5, 2010

5. Brewster L, Brey EM and Greisler HP: Blood Vessels. Principles of Tissue Engineering. 5th edition. Academic Press, Boston, 2020.

6. Schneider LA, Korber A, Grabbe S and Dissemond J: Influence of $\mathrm{pH}$ on wound-healing: A new perspective for wound-therapy? Arch Dermatol Res 298: 413-420, 2007.

7. Barar J and Omidi Y: Dysregulated $\mathrm{pH}$ in tumor microenvironment checkmates cancer therapy. Bioimpacts 3: 149-162, 2013.

8. Gerweck LE and Seetharaman K: Cellular pH Gradient in tumor versus normal tissue: Potential exploitation for the treatment of cancer. Cancer Res 56: 1194-1198, 1996.

9. Livak KJ and Schmittgen TD: Analysis of relative gene expression data using real-time quantitative PCR and the 2(-Delta Delta $\mathrm{C}(\mathrm{T})$ ) method. Methods 25: 402-408, 2001.

10. Arnaoutova I, George J, Kleinman HK and Benton G: The endothelial cell tube formation assay on basement membrane turns 20 : State of the science and the art. Angiogenesis 12: 267-274, 2009.

11. Arnaoutova I and Kleinman HK: In vitro angiogenesis: Endothelial cell tube formation on gelled basement membrane extract. Nat Protoc 5: 628-635, 2010.
12. Koh W, Stratman AN, Sacharidou A and Davis GE: In vitro three dimensional collagen matrix models of endothelial lumen formation during vasculogenesis and angiogenesis. Methods Enzymol 443: 83-101, 2008

13. Baker CD, Ryan SL, Ingram DA, et al: Endothelial colonyforming cells from preterm infants are increased and more susceptible to hyperoxia. Am J Respir Crit Care Med 180: 454-461, 2009.

14. Hou HH, Hammock BD, Su KH, et al: N-terminal domain of soluble epoxide hydrolase negatively regulates the VEGFmediated activation of endothelial nitric oxide synthase. Cardiovasc Res 93: 120-129, 2012.

15. Nemeno-Guanzon JG, Lee S, Berg JR, Jo YH, Yeo JE, Nam BM, Koh YG and Lee JI: Trends in tissue Engineering for blood vessels. J Biomed Biotechnol 2012: 956345, 2012.

16. Catto V, Farè S, Freddi $G$ and Tanzi MC: Vascular tissue engineering: Recent advances in small diameter blood vessel regeneration. ISRN Vasc Med 2014: 27, 2014

17. Ncube S, Akankwasa NT, Sibanda P and Ndlovu LN: Nanofibres for blood vessel tissue engineering: A review. MSAIJ 12 218-225, 2015

18. Ziegler T and Nerem RM: Tissue engineering a blood vessel: Regulation of vascular biology by mechanical stresses. J Cell Biochem 56: 204-209, 1994.

19. Davey B, Halliday T and Hirst M: Human Biology and Health: An Evolutionary Approach (Health and Disease). Open University Press, Philadelphia, PH, 2001.

20. Tilton RG, Hoffmann PL, Kilo $\mathrm{C}$ and Williamson JR: Pericyte degeneration and basement membrane thickening in skeletal muscle capillaries of human diabetics. Diabetes 30: 326-334, 1981.

21. Tresoldi C, Pellegata AF and Mantero S: Cells and stimuli in small-caliber blood vessel tissue engineering. Regen Med 10: 505-527, 2015

22. Iruela-Arispe ML and Davis GE: Cellular and molecular mechanisms of vascular lumen formation. Dev Cell 16: 222-231, 2009.

23. Schulz E and Münzel T: Lumen size matters: Role of protein disulfide Isomerase A1 in vascular remodeling. Hypertension 67 : 488-489, 2016

24. Smith GA, Howell GJ, Phillips C, Muench SP, Ponnambalam S and Harrison MA: Extracellular and Luminal $\mathrm{pH}$ Regulation by Vacuolar H+-ATPase isoform expression and targeting to the plasma membrane and endosomes. J Biol Chem 291: 8500-8515, 2016.

25. Zhao L, Cui L, Jiang X, Zhang J, Zhu M, Jia J, Zhang Q, Zhang J, Zhang D and Huang Y: Extracellular $\mathrm{pH}$ regulates autophagy via the AMPK-ULK1 pathway in rat cardiomyocytes. FEBS Lett 590: 3202-3212, 2016.

26. Dechant R, Saad S, Ibáñez AJ and Peter M: Cytosolic pH regulates cell growth through distinct GTPases, Arf1 and Gtr1, to promote Ras/PKA and TORC1 activity. Mol Cell 55: 409-421, 2014.

27. Ye RC: The relationship of $\mathrm{pH}$ of the granulation tissue and the take of the skin graft. Plast Reconstr Surg (1946) 19: 213-217, 1957.

28. Findlay $M$ and Isles $C$ : Disorders of Acid Base Balance. In: Clinical Companion in Nephrology. Springer International Publishing, Switzerland, 2015.

29. Cheng HM and Jusof F: Acid-Base Balance. Springer, Singapore, pp177-185, 2018.

30. Chaves MH, Wolf AR, Nascimento KA, Nawcki D, Feustel GM, Bettega PV, Ignacio SA, Brancher JA, Tannous LA, Werneck RI, et al: Sialochemical analysis in polytraumatized patients in intensive care units. PLoS One 14: e0222974, 2019.

(i) $($ ) This work is licensed under a Creative Commons Attribution-NonCommercial-NoDerivatives 4.0 International (CC BY-NC-ND 4.0) License. 